MATTHEW WEBB

\title{
TAKAMORE V CLARKE: TIKANGA AND MERITS-BASED RESOLUTION OF BURIAL DISPUTES, A JUST OUTCOME?
}

Laws 489: Research Essay

FACULTY OF LAW

TE WHARE WÁNANGa O TE ŨPOKO O TE IKA A MĀUI

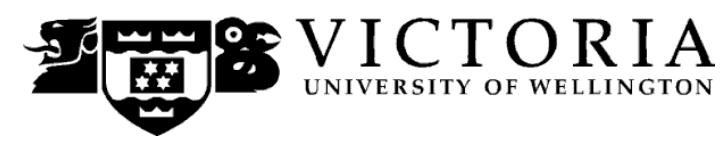

2013 


\begin{abstract}
Burial disputes are something of a novelty in New Zealand. Most are resolved amicably by those with ties to the deceased. The exception to has been the long-running case of Takamore v Clarke, the matter finally being resolved by the Supreme Court this year. Burial disputes raise fundamental issues of religious and cultural identity (including tikanga Māori), personhood, and the meaning of family. Despite their rarity in New Zealand, the response of the law in resolving such disputes should "fit the fuss", having regard to the context in which they arise. This essay begins by discussing the form of resolution advocated for by the majority and minority in Takamore. Their respective approaches are essentially the same, especially with regards to tikanga Māori. This is one of Court intervention coupled with a merits-based assessment of the dispute. However the Court failed to apprehend there was no pressing need for burial, prior to creating a solution of general application. The experience of comparable jurisdictions, where speedy resolution has been necessary (such as Australia) demonstrates that the role of the Court applying such a test in burial disputes is misconceived. Rather than providing "justice" for the parties concerned, merits-based resolution produces unfair and unconvincing outcomes. The more just response is to ensure the parties never get to Court, via mediation. Insofar as agreement is not possible, the role of the Court should be supervisory in the application of a prescriptive test emphasising expediency and ensuring the dispute is resolved out of Court.
\end{abstract}

Keywords: burial disputes, tikanga Māori, merits-based assessment, Court intervention, mediation, prescriptive test 
Table of Contents

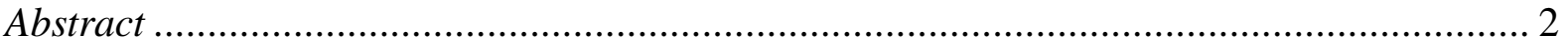

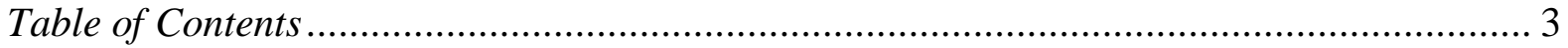

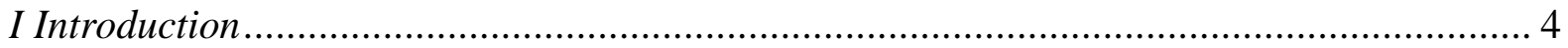

II The Resolution of Burial Disputes Under Takamore ...................................................... 5

A Factual Background ................................................................................................ 5

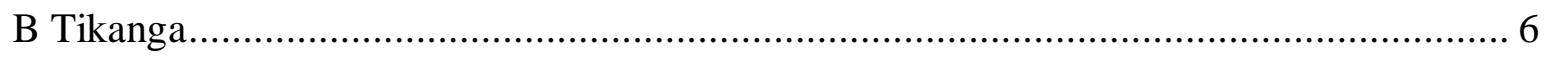

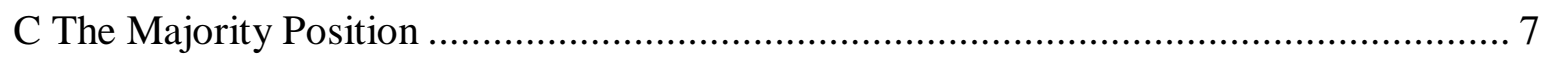

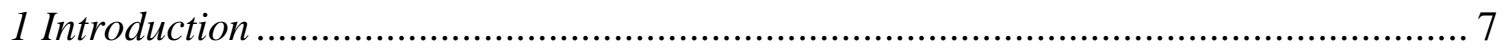

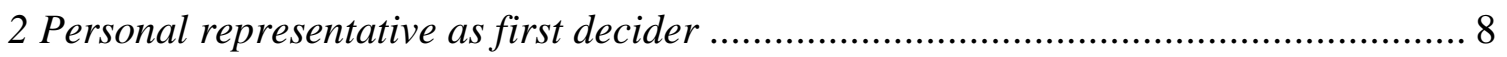

3 A less absolute form of the first decider rule ......................................................... 9

4 Contrast: a more stringent form of review in equity .............................................. 10

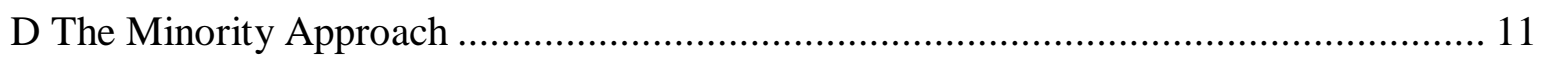

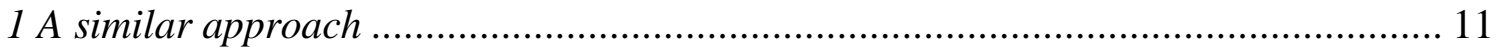

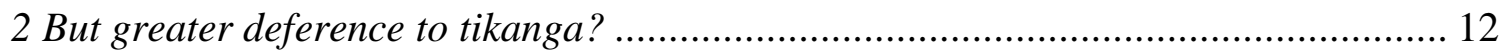

3 Is the minorities test for Court intervention different to the majorities? ...................... 14

III Burial Dispute Resolution Under Takamore: A Critique ............................................... 15

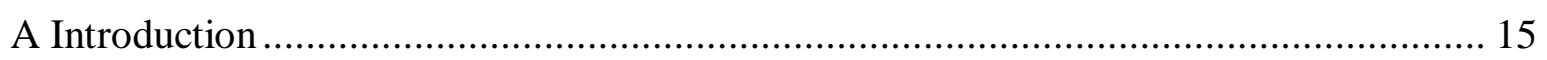

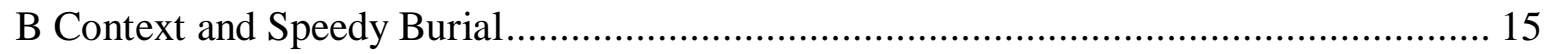

C The Corollary of a Speedy Burial ............................................................................ 18

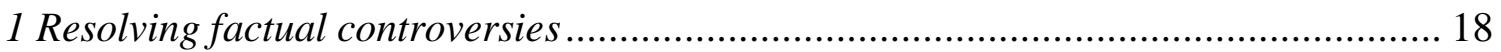

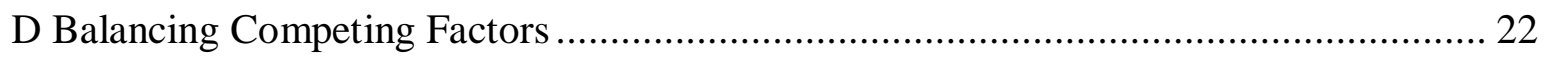

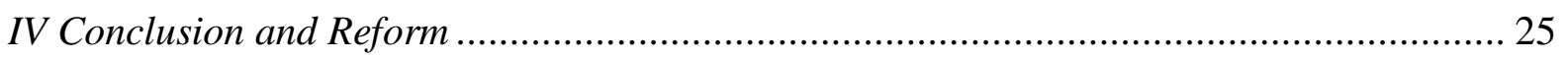

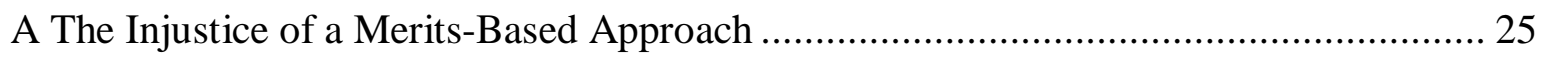

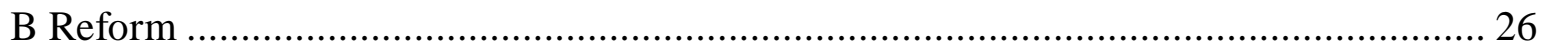

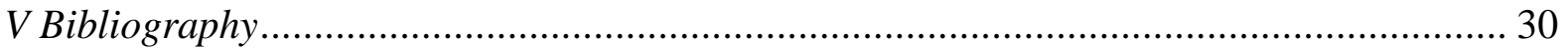

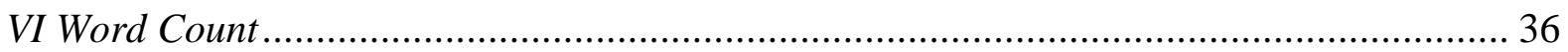




\section{Introduction}

When a person dies, happily most disputes as to location and manner of disposal of their remains are resolved expediently and amicably outside of litigation, or do not arise in the first place. ${ }^{1}$ In New Zealand this is illustrated by the lack of case law on how burial disputes are to be resolved. ${ }^{2}$ Situations do arise where parties to such disputes are unable to resolve the matter without third party assistance. This has been the case in the protracted burial dispute in Takamore v Clarke ("Takamore"). Last year, the Supreme Court unanimously dismissed the appeal of Josephine Takamore (the "appellant") ${ }^{3}$ in her claim that she had the ultimate right to dispose of her deceased brothers remains (James Takamore "the deceased"). ${ }^{4}$ His partner Denise Clarke (the "respondent") was successful in having her original claim to the High Court vindicated, ${ }^{5}$ allowing her to decide the place of burial. ${ }^{6}$ However the majority (Tipping, McGrath, and Blanchard JJ) ${ }^{7}$ and minority (Elias CJ, William Young J) differed on the reasons the appeal should be allowed. ${ }^{8}$ As this case demonstrates, amicable inter-parties resolution of burial disputes is not always possible. ${ }^{9}$ A legal solution is needed. ${ }^{10}$ In an area of law which impacts on the feelings, human rights, and cultural practices of parties to the conflict, any legal response must be analytically sound, convincing, and consistent with pertinent policy objectives. ${ }^{11}$

The focus of this paper will be on analysing the respective approaches of majority and minority in resolving this case, with reference to tikanga Māori ("tikanga") as an illustration of how they would work in practice. Closer analysis (again with reference to tikanga) demonstrates there is no material difference in their approaches, contrary to judicial opinion in the case. ${ }^{12}$ Both majority and minority resolve this case applying a "merits-based" approach. It will then be argued that counter-intuitively, Court imposed

\footnotetext{
${ }^{1}$ Takamore v Clarke [2012] NZSC 116, at [2], [10]. For brevities sake, such disputes will be referred to as "burial disputes" (though this is intended to include other forms of disposal such as cremation).

${ }^{2}$ Ibid at [62], [112]-[120], Murdoch v Rhind [1945] NZLR 425 (SC), Tapora v Tapora CA206/96, 28 August 1996.

${ }^{3}$ See Clarke v Takamore [2010] 2 NZLR 525 (HC) at [18], Takamore v Clarke [2011] NZCA 587, [2012] 1

NZLR 5 at [7], Takamore v Clarke (SC), above n 1, at [3]-[4].

${ }^{4}$ At [108], [170], [175].

${ }^{5}$ Clarke v Takamore [2010] 2 NZLR 525 (HC).

${ }^{6}$ At [107].

${ }^{7}$ At [154] and [160] per Tipping, McGrath and Blanchard JJ.

${ }^{8}$ At [90] per Elias CJ, [175], [214] per William Young J.

${ }^{9}$ Takamore $v$ Clarke (CA), above n 3, at [6].

${ }^{10}$ Calma v Sesar (1992) 106 FLR 446 (NTSC) at 452.

${ }^{11}$ At [1].

${ }^{12}$ At [213].
} 
resolution coupled with a merits-based test does not produce more "just" outcomes in burial disputes. This can be demonstrated with reference to the application of tikanga (or other cultural beliefs) in resolving burial disputes. In this sense tikanga is just one example of the systematic problems arising in the application of a merits-based approach. Such problems are illustrated by developments in a number of Australian decisions, where significantly more case law has been generated. A detailed analysis of reform is beyond the scope of this paper, but a tentative solution could be a mandatory mediation regime for burial disputes. The ultimate argument is that, by their very nature, burial disputes are not amenable to just resolution in the sense that a range of options are often open. Requiring the law to satisfy such a criterion is unmerited, and other policy factors should be determinative in this context.

\section{The Resolution of Burial Disputes Under Takamore}

\section{A Factual Background}

The deceased passed away on the 17 August 2007 in Christchurch. ${ }^{13}$ He was born in 1952, Waioweka, south of Opotiki, in the Bay of Plenty. His whānau's marae was Kutarere, a Te Upokerehe (hapū) marae ${ }^{14}$ governed by Tūhoe tikanga. ${ }^{15}$ The deceased's teenage and early adult years were spent in his tribal homelands and in close contact with his family, however sometime prior to1985 he began seeing the respondent (who was from Christchurch). ${ }^{16}$ In 1985 they had their first child. ${ }^{17}$ The respondent then began to miss her family in Christchurch, and so returned with their child. The deceased followed her and they remained settled in Christchurch until his death.

During his time in Christchurch the deceased's contact with his family from Kutarere was infrequent, and he only visited his family twice prior to his death. ${ }^{18}$ There was also evidence that the deceased had turned his back on his cultural heritage, ${ }^{19}$ though the High Court finding to this effect was overturned by the majority of the Court of Appeal ${ }^{20}$ and

\footnotetext{
${ }^{13}$ Takamore $v$ Clarke (SC), above $\mathrm{n} 1$, at [13].

${ }^{14}$ Clarke v Takamore (HC), above n 3, at [10].

${ }^{15}$ Ibid at [10]-[11].

${ }^{16}$ At [13].

17 Ibid.

${ }^{18}$ At [14].

${ }^{19}$ At [14]-[16], [88].

${ }^{20}$ Takamore v Clark (CA), above n 3, at [156]-[158] per Glazebrook and Wild JJ, compare at [267] per Chambers J.
} 
unanimously in the Supreme Court. ${ }^{21}$ His body remained at a local marae in Christchurch, pending funeral and burial there. ${ }^{22}$ However his northern relatives arrived and laid claim to his body, arguing he should be returned to the Bay of Plenty and buried there. ${ }^{23}$ A heated discussion ensued, with neither party acquiescing to the others claim.

The next day, the deceased's mother called to tell the respondent she and her family were waiting at the marae for her to return so the discussions could resume, ${ }^{24}$ however the respondent was unwilling to return, fearing for the safety of herself and her children. ${ }^{25}$ They subsequently uplifted the deceased's remains and took them back to be buried at the Kutarere Marae. ${ }^{26}$ The respondent obtained an interim injunction restraining the burial of the deceased, and requiring the police to take his remains into custody pending resolution. ${ }^{27}$ However the police did not attempt to serve the order. ${ }^{28}$ Consequently the deceased's body was interred at Kutarere and has remained there during the subsequent litigation. This had a significant impact on how the case was dealt with procedurally, as there was no pressure in terms of ensuring the case was dealt with speedily. This impacted on how quickly the matter has been resolved. The respondent subsequently issued proceedings in the High Court seeking an order allowing her to disinter the deceased's remains and deal with them as she saw fit. ${ }^{29}$

\section{B Tikanga}

Tikanga will play an important part later in this paper, when comparing the differences between the majority and minority approach to resolution of burial disputes, and also in illustrating the difficulties of a merits-based test. It is therefore necessary to define it. However the present case demonstrates that defining tikanga is not overly helpful in the sense that the phrase is more illustrative than definitive. ${ }^{30}$ Different potential meanings

\footnotetext{
${ }^{21}$ Takamore v Clarke (SC), above n 1, at [17] per Elias CJ, at [110] per Tipping, McGrath and Blanchard JJ.

${ }^{22}$ Takamore $v$ Clarke (HC), above n 3, at [2].

${ }^{23}$ Ibid at [3].

${ }^{24}$ Takamore v Clarke (CA), above n 3, at [42].

${ }^{25}$ Ibid.

${ }^{26}$ At [43].

${ }^{27}$ Clarke v Takamore (HC), above n 3, at [6].

${ }^{28}$ Ibid. The body had not been interred at the time of the Police arrived to serve the order, however it seems likely the officers entrusted with serving the order were hesitant to do so because this could have resulted in a physical altercation with members of the deceased's family and others present at the funeral (as the injunction required the Police to take the body into their custody).

${ }^{29}$ Ibid at [9].

${ }^{30}$ Fiona Wright ““"Tikanga Māori” What is it doing in New Zealand law?” (LLM Research Paper, Law, Religion and Values (Laws 527), Victoria University of Wellington, 2006) at 24.
} 
indicate what kind of things tikanga encapsulates (e.g. rules, values, practices, polite behaviour), but do not specify what their content is. In this case (though not necessarily every burial dispute) ${ }^{31}$ the relevant features of the burial tikanga were well documented and subject of extensive expert testimony. ${ }^{32}$ This makes it unnecessary to carry out a detailed discussion of the phrase. For present purposes a working definition is provided in the Law Commission paper "Māori Custom and Values in New Zealand Law" as "...a body of rules and values developed by Māori to govern themselves - the Māori way of doing things." ${ }^{33}$ The key principles of Tūhoe tikanga in the present case were summarised by counsel for the appellant, in the High Court decision. ${ }^{34}$

C The Majority Position

1 Introduction

In this part of the paper it is argued that there is no material difference between the majority and minority approach in resolving burial disputes; as they both provide the Court decides which party has the best claim. William Young J, in concurring with Elias CJ, stated that “[the Chief Justice's approach] does, however, involve a substantial concession to custom in that it precludes any single participant (who may not be a family member) determining the outcome.” ${ }^{35}$ A closer analysis of the Supreme Court's respective approaches reveals this conclusion is false.

Both majority and minority were heavily influenced by the percieved importance of creating a legal framework which allows for Court supervision of burial decisions; whether the first decision is made by the deceased's personal representative, or someone else. Additionally they wished to ensure such supervision was carried out in a manner which allowed a burial decision to be substituted if the Court thought it was incorrect, as opposed to a higher threshold for intervention.

The overriding policy factor the Court considered to justify some form of review right (and the application of a merits-based test) in burial disputes was the importance of maintaining the “...flexibility to respond to the justice of the case.”" 36 This can be seen expressly in the

\footnotetext{
${ }^{31}$ See Reece $v$ Little [2009] WASC 30 at [72]-[74].

${ }^{32}$ Clarke v Takamore (HC), above n 3, at [57], Takamore v Clarke (CA), above n 3, at [58]-[92].

${ }^{33}$ Law Commission Māori Custom and Values in New Zealand Law (NZLC SP9, 2001) at 73.

${ }^{34}$ Takamore v Clarke (HC), above n 3, at [57].

${ }^{35}$ At [213].

${ }^{36}$ At [75].
} 
minority’s judgment. ${ }^{37}$ And it can also been seen through the majority's unwillingness to accept burial decisions of personal representatives were to be reviewed in accordance with equitable jurisdiction of the High Court to review a trustee's decision. ${ }^{38}$ Combined, this reflects the Court's concern that burial disputes should be resolved in accordance with their merits. ${ }^{39}$ Later in the paper it will be argued that a merits-based test is inappropriate, despite the importance of resolving such disputes fairly.

\section{Personal representative as first decider}

Two common themes can be distilled from the majority and minority approaches: firstly the importance of Court review, and secondly ensuring the nature of such review allows the Court to intervene if it disagrees with the decision of the personal representative or other person who may have made burial arrangements. According to the majority, burial disputes are resolved in accordance with the common law framework governing the rights and obligations of executors to a deceased person's estate. ${ }^{40}$ In the event of an intestacy, the administrator is in the same position as the executor. ${ }^{41}$ The administrator is appointed in accordance with the priority in favour of those with a beneficial interest in the deceased's estate (due to succession), as set out in the High Court Rules and the Administration Act $1968 .{ }^{42}$ However the High Court has an overriding discretion to grant another person letters of administration. ${ }^{43}$ The executor was traditionally said to have the duty and right to dispose of the deceased's remains, in the sense that they have the ultimate right to decide the manner and location of disposal, but also a duty to ensure that disposal occurred. ${ }^{44}$ This is conceived by William Young $\mathrm{J}$ as the stronger version of the "first decider" rule, whereby the executor is the paramount decision-maker with regards to disposal, and this is not subject to appeal or any other form of review. ${ }^{45}$

Under such an approach the significance of tikanga (and other relevant factors, such as spiritual beliefs) would be dependent on the views of the executor or administrator, as in

\footnotetext{
37 Ibid.

38 At [162].

${ }^{39}$ At [75]-[86] per Elias CJ, at [156] per Tipping, McGrath and Blanchard JJ.

${ }^{40}$ Takamore v Clarke (SC), above n 1, [112]-[120].

${ }^{41}$ At [145], [171].

42 Administration Act 1968, s 77, High Court Rules, r 27.35(3)-(4).

${ }^{43}$ Section 6, Takamore v Clarke (SC), above n 1, at [148], Burrows v HM Coroner for Preston [2008] 2 FLR 1225 (QB) at [17].

${ }^{44}$ Ibid, Williams $v$ Williams (1882) 20 ChD 659.

45 At [172].
} 
lieu of any right of appeal their view on the matter is determinative. As this would mean recognition and protection of tikanga turned on the whims of the particular personal representative (as there is no ability for an aggrieved party seek review of the decision), it is difficult to conceive how such a rule could ever sufficiently ensure the decision is made with proper reference to tikanga. More generally there would be no appellate function for the Courts, to ensure that the personal representative reached the "correct" decision.

\section{A less absolute form of the first decider rule}

Consequently, the majority adopts a weaker form of the first decider rule. The decision of the deceased's personal representative stands unless successfully challenged in the High

Court. ${ }^{46}$ Importantly the first decider rule is only engaged where the family of the deceased is unable to reach a decision as to disposal, ${ }^{47}$ and secondly review (where sought) would proceed largely on the basis of a de novo rehearing ${ }^{48}$ of the personal representatives decision, with perhaps no, or little deference being paid to their original decision. ${ }^{49}$ This is to be distinguished from a stricter review approach, such as requiring the personal representative to have acted in bad faith or ultra vires. ${ }^{50}$ The Court may intervene where, having regard to all the relevant circumstances (such as spiritual and cultural practices and beliefs, and other family and personal interests), it believes the decision made by the personal representative was not appropriate. ${ }^{51}$ The demonstrates the first theme noted earlier, the majority was concerned with establishing a supervisory role of the Court to ensure those aggrieved with burial decisions had the means to challenge them. Hence it adopts a weaker form of the first decider rule, though admittedly this was also supported by developments in comparable jurisdictions rather than solely policy considerations. ${ }^{52}$

\footnotetext{
${ }^{46}$ At [154], [160].

47 Ibid.

${ }^{48}$ Takamore v Clarke (SC), above n 1, at [172], Andrew Beck Principles of Civil Procedure (3rd ed, Brookers, Wellington, 2012) at 235, Shotover Gorge Jet Boats Ltd v Jamieson [1987] 1 NZLR 437 (CA).

${ }^{49}$ At [160]-[162].

${ }^{50}$ Law Commission Court Jurisdiction, Trading Trusts and Other Issues: Review of the Law of Trusts

(NZLC IP5, 2011) 10-13.

51 Takamore v Clarke (SC), above n 1, at [162].

52 At [121]-[142].
} 
4 Contrast: a more stringent form of review in equity

The majority's approach is in contrast from the standard of review advocated for by counsel for the respondent. ${ }^{53}$ Its dismissal of such an approach highlights a key consideration which underlies its decision; that the supervisory role of the Court needed to be unimpeded by a legal test which creates a heightened threshold to be met before the decision of the personal representative will be set aside. This is the second of the two discussed themes. Counsel made reference to the source of the power of review of an executor's decision as to burial being equity and therefore review would be via the High Court's supervisory jurisdiction of executors/administrators as trustees of the deceased's estate $^{54}$ The majority dismissed the argument that the source of the High Court's review jurisdiction of burial decision is equity. ${ }^{55}$ The correctness of such a decision will not be considered, rather its significance for present purposes demonstrates the majority was seized of alternatives to a de novo rehearing but dismissed them because of its concern that burial disputes be resolved based on their merits.

Briefly, if the personal representatives decision was required to be reviewed in accordance with principles governing the review of the exercise of a trustee's discretionary power, ${ }^{56}$ intervention would only be justified where it could be shown the trustee had acted in bad faith or ultra vires. ${ }^{57}$ The two most pertinent sub-grounds of "bad faith" are a failure to take into account, understand, or give genuine and honest consideration to relevant matters, or conversely, take into account irrelevant matters, and where this amounted to a breach of a fiduciary obligation. ${ }^{58}$ The weight to be given to such factors would seem to be up to the trustee, recent New Zealand decisions hold that a trustee's decision cannot be reviewed because they are "unreasonable" (in the Wednesbury sense). ${ }^{59}$

\footnotetext{
53 At [162].

${ }^{54}$ At [74].

55 Ibid.

${ }^{56}$ Noel C Kelly and others Garrow and Kelly Law of Trusts and Trustees (6th ed, LexisNexis, Wellington, 2005) at 512.

${ }^{57}$ Gailey v Gordon [2003] 2 NZLR 192 (HC) at [83].

${ }^{58}$ See Noel C Kelly, above n 56, at 516-519 and Law Commission, above n 50, at 12, compare Re HastingBass [1974] 2 All ER 193 and Futter v Futter [2011] EWCA Civ 197.

${ }^{59}$ For the affirmative view see Craddock $v$ Crowhen (1995) 1 NZSC 40,331 at 12, Wrightson Ltd $v$ Fletcher Challenge Nominees Ltd (1998) 1 NZSC 40,388, Re The Motorola Superannuation Fund [2001] 3 NZLR 50 (HC), compare with Gailey v Gordon, above n 57, at [89], Noel C Kelly, above n 56, at 521-522. See also Associated Provincial Picture Houses Ltd $v$ Wednesbury Corporation [1947] EWCA Civ 1.
} 
Even if a personal representative failed to take into account a relevant matter the party seeking to review the decision would need to show a breach of the personal representative's fiduciary obligations. Traditional fiduciary obligations (which focus on the personal representatives role in disposing of the deceased's estate) imposed on trustees do not correlate with the discretionary power of a personal representative to decide where the deceased is buried. ${ }^{60}$ If the trustee did take the relevant factor into account, then the weight it was given is not a ground for challenge under recent authority. It is therefore difficult to ever envisage a scenario where failure to have regard to a relevant factor (or regard to an irrelevant factor) would allow the representatives decision to be successfully challenged. The likely remedy would be to remit the decision back to the trustee to make again, having regard to the relevant factor. Stakeholders in the dispute would be left with no effective remedy, as the personal representative might reach the same decision again after considering the relevant factor (or ignoring the irrelevant one). The reasonableness of the decision would be unable to be challenged.

Such an approach is the antithesis of a merits-based test, which allows the Court to make its own decision based on all the circumstances. In dismissing such an approach, the majority clearly wished to avoid a situation where Court review was restricted, so as to allow it to ensure burial disputes are justly resolved in accordance with their merits. ${ }^{61}$

D The Minority Approach

\section{A similar approach...}

The Chief Justice, along with William Young J, disagreed with the majority on their interpretation of relevant case law governing a personal representative's right as the first decider. ${ }^{62}$ They thought that personal representatives did not have a first decider role, and because of the lacuna their approach creates the Chief Justice determines that the High Court has jurisdiction to resolve burial disputes via its inherent jurisdiction. Executors and other family members of the deceased have the "privilege" of burial, which means in lieu

\footnotetext{
${ }^{60}$ Takamore v Clarke (SC), above n 1, at [74]. See N Richardson Nevill's Law of Trusts, Wills and Administration (10th ed, LexisNexis, Wellington, 2010) at 217-252.

${ }^{61}$ At [162].

${ }^{62}$ At [8], [90] per Elias CJ, at [173], [214] per William Young J.
} 
of dispute they have sufficient authority to dispose of the deceased remains. ${ }^{63}$ The inherent jurisdiction of the High Court can be properly invoked where the dispute is unable to be settled outside of Court, such as through familial discussion or tikanga. ${ }^{64}$

In exercising its inherent jurisdiction, the minority's approach in resolving burial disputes is very similar to the majorities in that it provides for ultimate determination by the High Court. ${ }^{65}$ Those with standing can invoke the inherent jurisdiction, and the High Court will determine the matter with reference to the wider circumstances of the case, ${ }^{66}$ including personal relationships the deceased had and their closeness, ${ }^{67}$ cultural and spiritual values, ${ }^{68}$ and other relevant factors. The common themes of Court imposed resolution and merits-based test can be seen in the minorities approach also.

\section{But greater deference to tikanga?}

William Young J disagreed with the conclusion that the majority and minority approaches treated tikanga in a similar fashion. ${ }^{69}$ This was because minority approach provided that no one person has a definitive say in what happens to the remains of the deceased (prior to invoking the inherent jurisdiction of the High Court), the minority's approach was argued by William Young $\mathrm{J}$ to better reflect the Tūhoe burial tikanga. ${ }^{70}$ The minority approach was said to reflect one of its values, that is, the resolution of burial disputes are not a decision for one person to make, but rather a collective decision in which the views of no one person are determinative. ${ }^{71}$ The majority approach allows one person to resolve the dispute; the personal representative of the deceased. Tikanga, in contrast, requires such decisions to be made with reference to the whānau pani of the deceased. ${ }^{72}$ In the event of an impasse, a wider circle can be engaged with the aim of resolving the dispute (particularly those with cultural expertise). ${ }^{73}$ The decision is a collective one rather than for a particular individual.

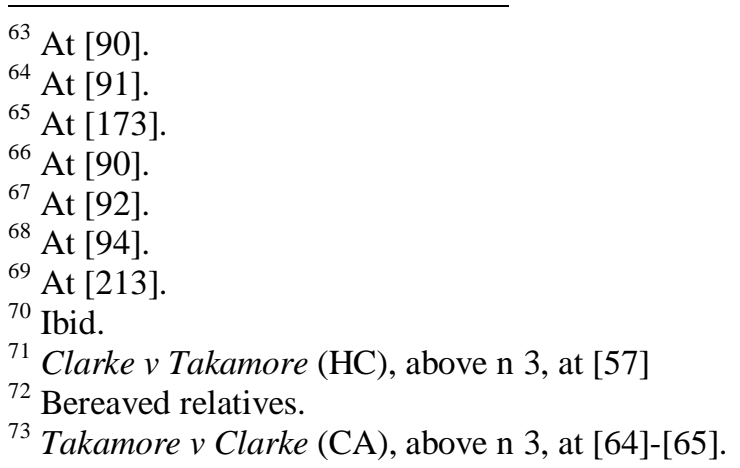


To an extent this is a misnomer, as Tūhoe tikanga does provide for an ultimate decisionmaker. It provides a set of values through which the merits of party's claims can be assessed objectively (such as where the deceased's placenta was buried). ${ }^{74}$ One party might be pressured into acquiescing to another's decision because, based on these criterion, they have an objectively "weaker" claim. Tikanga therefore envisages that a collective decision (i.e. one everyone agrees to) might not always be possible. Another example of this is the ability of one party to take the deceased's remains through force or stealth. ${ }^{75}$ What tikanga does allow for, is a process of wider consultation and values-based assessment of claimants burial wishes. It cannot sensibly guarantee that everyone will be happy with the ultimate decision or avoid the possibility that one person's decision

Confusingly William Young J's criticism of the majority approach seems to be that it fails to accommodate the latter point, that is it prescribes an ultimate decision-maker in the form of a personal representative. ${ }^{76}$ But Tūhoe tikanga must also deal with the situation where participants are unable to agree, and it provides for a process of debate and discussion to determine who this person should be, or alternatively allows one party to unilaterally seize the remains. This is the crux of the issue in the case - who ultimately gets to decide where the remains are buried? The key difference between majority and tikanga is how this is determined. Thus the more valid criticism, is the manner in which the majority approach determines who the ultimate decider is (i.e. who is the executor or administrator). This is in contrast to the process of wider consultation, debate, and merits-based assessment of respective claims required by tikanga. A closer reading of the respective approaches in this case demonstrates that, neither provides for tikanga prior to Court resolution in the sense just described.

Like the minority approach with respect to Court intervention, ${ }^{77}$ the first decider rule is only engaged where the family of the deceased is unable to agree. ${ }^{78}$ The first decider rule will only allow the personal representative to make a binding decision where familial resolution is not possible. This means that, under both approaches, the family of the deceased have considerable leeway to resolve the dispute themselves, in accordance with tikanga or some other approach. If this fails, the first decider rule is engaged. As with the

\footnotetext{
${ }^{74}$ Clarke v Takamore (HC), above n 3, at [57].

${ }^{75}$ Ibid.

${ }^{76}$ Takamore v Clarke (SC), above n 1, at [213].

${ }^{77}$ At [90].

${ }^{78}$ At [154].
} 
majority approach, the minority also does not provide for tikanga prior to Court resolution. $^{79}$

A number of persons have the "privilege of burial”. But the Chief Justice doesn’t specify the process or values which are to be brought to bear when determining which one of these persons has the best claim if they are in disagreement as to what is to happen to the deceased's remains. There is no process; the minority approach creates a free for all. Where dispute does arise seemingly those with the privilege are not permitted to exercise it, ${ }^{80}$ but the minority does not specify what the consequences would be if the party did proceed to bury the deceased in the absence of consent of other privilege-holders. By inference, there are none, as the facts of this very case would seem to indicate. Conclusively, the minority approach does not provide for or incentivise adherence to a particular process or set of values prior to Court resolution. There is no difference between either approach in terms of tikanga, the former provides for pre-Court resolution, the latter does not.

\section{Is the minorities test for Court intervention different to the majorities?}

One criticism Elias CJ made of the majorities approach was that it amounted to a "rule of law” or prescriptive based approach to resolving burial disputes. ${ }^{81}$ This distinction between a merits-based and a prescriptive based test is that the former resolves burial disputes based on the wider circumstances of the deceased's life and interested parties. Competing claims and factors are weighed (such as the importance of particular relationships, spiritual, and cultural practices) with the ultimate decision being made from the premise that there is one "normatively" correct outcome.

A prescriptive test or "rule of law approach" creates some form of rule (whether hard or rebuttable) which disposes of the dispute, usually characterised by lack of consideration of the merits of the disputes and a greater level of certainty prior to initiating proceedings. ${ }^{82}$ A paradigm example is the hard form of first decider rule, ${ }^{83}$ and another is statutory

\footnotetext{
${ }^{79}$ At [90]-[91] per Elias CJ.

${ }^{80}$ At [90].

${ }^{81}$ At [80]-[86].

${ }^{82}$ At [80]. For examples of the former and latter see Calma $v$ Sesar, above $n 10$ at 452, Meier v Bell SC Victoria BC9700457, 3 March 1997 at 10, compare Jones v Dodd [1999] SASC 125, at [53]-[55], Dodd v Jones [1999] SASC 458 at [30]-[32].

${ }^{83}$ At [174]-[175].
} 
regimes which prescribe that certain blood relatives have a presumptive right to dispose of the deceased's remains. ${ }^{84}$ It is questionable that, when viewed holistically (i.e. the role of the personal representative as first decider in conjunction with the capacity for Court review) the majority approach is really a prescriptive one, especially considering the review of the personal representative's decision occurs de novo. In this sense the Chief Justice was incorrect to say that the majority approach was a prescriptive one. The proposition that the majority and minority approach take a different approach to tikanga (or the resolution of burial disputes more generally) is categorically rejected. It is important to remember this when considering the efficacy of a merits-based approach: the majority and minority both apply a merits-based approach.

\section{Burial Dispute Resolution Under Takamore: A Critique}

\section{A Introduction}

The next part of this paper will begin from the premise that both the majority and minority approach start from the same position when resolving burial disputes. The efficacy of a merits-based test will be considered. This will be done with reference to tikanga, as a useful illustration of some of the difficulties that might arise in the application of such a test. The Chief Justice was well seized of issues arising from merits-based test, but did not think that these justified an alternative rules based approach. ${ }^{85}$ This position is contested, an in-depth analysis of merits-based test in the context of burial disputes demonstrates that such a test is unable to achieve its rationale; the just resolution of such disputes. In Australia there has been significantly more case law in resolving burial disputes, applying a merits-based test. ${ }^{86}$ With reference to these decisions it will be argued that a merits-based test (and the role of the Court in applying such a test) raises a number of insurmountable difficulties, and that an alternative means of resolving burial disputes should be adopted in New Zealand.

B Context and Speedy Burial

\footnotetext{
${ }^{84}$ Cremation, Interment and Funeral Services Act BC 2004 c 35, s 5.

${ }^{85}$ At [80]-[86] per Elias CJ, [138] per Tipping, McGrath and Blanchard JJ.

${ }^{86}$ Smith $v$ Tamworh City Council (1997) 41 NSWLR 680, Roaslind Atherton "Who owns your body?" (2003) 77 ALJ 178 at184-189, Calma v Sesar, above n 10, at 452, Meier v Bell, above n 82, at 5, Dodd v Jones, above n 82, at [30]-[31], Jones $v$ Dodd, above n 82, at [51].
} 
It is important to note the context in which burial dispute are resolved, as this highlights a significant issue with a merits-based test. Understandably in most cultures and societies, there is an emphasis on ensuring the deceased is buried quickly after death. ${ }^{87}$ This is an expression of an important principle; that is speedy burial. Burial is integrally tied up with the grieving process, and a delayed burial results in lack of closure for loved ones of the deceased and compounds their suffering further. ${ }^{88}$ The natural correlation is that burial disputes, where litigated must be resolved quickly, in order to save the feelings of those involved. ${ }^{89}$

This feature's importance is reflected in the way Courts have been unwilling to subject such disputes to full hearings or even reserve their decisions, and the consequential delays. $^{90}$ As a theme, speedy resolution of burial disputes has been noted as an important concern in New Zealand, despite our lack of case law in this area. ${ }^{91}$ Additionally, it can be seen in the majority's refusal to require the deceased's personal representative to carry out a consultation process with interested parties. ${ }^{92}$ This conclusively demonstrates that a key feature when resolving burial disputes is the importance of ensuring that such resolution occurs quickly. Also important to note, this is the paramouncy of a such a principle, which which takes precedence over other important policy considerations, such as subjecting burial disputes to fuller procedural requirements.

The next point to note is that, because of the unique facts of the present case, the decision was not required to be disposed of quickly. This is because the deceased remains were not held in state prior to the dispute, which meant there was no pressing need to ensure that he was properly buried. ${ }^{93}$ And this resulted from the forced taking of the deceased's remains, and the consequent removal to the North Island for burial. ${ }^{94}$ General practice in burial disputes in Australia is that reliance is placed on the parties not to make burial arrangements until the matter has been determined by the Court, ${ }^{95}$ but invariably in some

\footnotetext{
${ }^{87}$ Takamore v Clarke (SC), above n 1, at [86], Jones $v$ Dodd, above n 82, at [40].

${ }^{88}$ Ugle v Bowra [2007] WASC 82 at [1].

${ }^{89}$ Ibid.

${ }^{90}$ Dodd $v$ Jones, above n 82, at [5]-[6]. Jones $v$ Dodd, above n 82, at[12], Mourish $v$ Wynee [2009] WASC 85 at [4], Keller v Keller [2007] VSC 118 at [4], [9], Ugle v Bowra, above n 88, at [1], [3], Reece v Little, above n 31, at [16], [23].

${ }^{91}$ Murdoch v Rhind, above n 2, at 426.

${ }^{92}$ At [156].

${ }^{93}$ Clarke v Takamore (HC), n 3, at [6]-[7].

${ }^{94}$ Takamore $v$ Clarke (SC), n 1, at [19].

${ }^{95}$ Meier $v$ Bell, above n 82, at 1, Jones v Dodd, above n 82, at [1]-[8].
} 
cases a free for all will eventuate. This is when interim injunctions become a useful tool to prevent one party attempting to pre-determine the outcome of the dispute. ${ }^{96}$

The New Zealand Police refused to serve the interim injunction obtained by the respondent, ${ }^{97}$ which meant that when the Takamore whānau buried the deceased they were neither in contempt of court, nor required to disinter the body and give up custody to the Police to purge their contempt. ${ }^{98}$ The terms of the order required that the Police to restrain the burial of the deceased. ${ }^{99}$ The order had no legal effect prior to service ${ }^{100}$ or being brought to the attention of non-parties, and became nugatory once burial had occurred. It was overtaken by the subsequent litigation as well as the fact the injunction was aimed at restraining burial rather than requiring disinterment. ${ }^{101}$ The deceased was buried, and it is in this state he remained for the subsequent litigation. And as he had been buried there was no perceived need (especially judicial) to ensure the matter was quickly disposed of. ${ }^{102}$ Finally, this had a significant impact on the application of a merits-based approach; it meant the Court had considerably more time to fully resolve the matter.

This can be seen in the sheer length of time the Takamore dispute has ensued, with proceedings commenced in August 2007 by the respondent, ${ }^{103}$ and the appeal to the Supreme Court being disposed of on 18 December 2012. ${ }^{104}$ Hearings in this case (especially in the High Court, where the lengthiest aspect of hearings occurred, the calling of evidence $)^{105}$ seem to sit in the middle range of potential hearing times. ${ }^{106}$ More

\footnotetext{
${ }^{96}$ Calma v Sesar, above n 10, at 447-448, Leeburn v Derndorfer [2004] VSC 172 at [6], Mourish v Wynee, above n 90, at [2]. Mankletow v Public Trustee [2001] WASC 290 at [1].

${ }^{97}$ High Court Rules, r 6.1, see Footnote 28.

${ }^{98}$ High Court Rules, rr 7.48, 17.3, 17.84, 17.86, Soljan v Spencer [1984] 1 NLZR 618 (CA).

99 Takamore v Clarke, above n 3, at [6].

${ }^{100}$ Footnote 98.

${ }^{101}$ Re Supply of Ready Mixed Concrete (No.2) [1992] 2 QB 213 at 239, Siemer v Solicitor-General [2013] NZSC 68.

102 This can be seen in the length of time between hearing and when the judgments of the respective Courts came out, especially at the Court of Appeal and Supreme Court levels, all three decisions being reserved. The High Court decision came out 14 days after the hearing, 293 days for the Court of Appeal and 153 for the Supreme Court. 293 and 153 days, would be seen as incredibly an incredibly lengthy period for the deceased body to remain unburied (which of course didn't occur in this case), and this is demonstrated by general practice in Australia where the turnaround of decisions is much quicker, for example see Mankletow $v$ Public Trustee, above n 96 (one day), AB v CD [2007] NSWSC 1474 (four days), Burrows v Cramley [2002] WASC 47 (1 day), Keller v Keller, above n 90 (one day), Doherty v Doherty [2006] QSC 257 (31 days). ${ }^{103}$ Clarke v Takamore (HC), above n 3, at [6].

${ }^{104}$ Takamore $v$ Clarke (SC), above n 1.

105 The hearing in the High Court went for three days, with the appeal to the Court of Appeal being heard in one, and the Supreme Court appeal over two.

${ }^{106}$ For cases where the matter was heard over one day see Ugle v Bowra, above n 88, Meier v Bell, above $\mathrm{n}$ 82, Leeburn v Derndeorfer, above n 96, Jones v Dodd, above n 82, though compare Dodd v Jones, above n
} 
importantly, the time between hearing and decisions demonstrates that the Courts had ample time to consider the matter fully; both in terms of the evidence that was called and time to produce a fully-reasoned and cogent judgment. ${ }^{107}$ A stark contrast can be drawn between the timeframe for resolution in Takamore and the Western Australian decision in Ugle, where the matter was resolved within two days of commencing the proceedings because of the pressing need to ensure burial. ${ }^{108}$

Neither the majority nor minority seems to have apprehended that Takamore differed to most burial disputes in the sense that speedy resolution was not required. ${ }^{109}$ The majority stresses that the first decider approach provided for more "prompt decisions" where a burial dispute arises, and thereby highlights their view that expeditious burial is a positive aspect of their approach. ${ }^{110}$ But there is only limited assessment of how this interrelated with a merits-based approach to reviewing the decision of the deceased's personal representative. ${ }^{111}$ With regards to the minority, Elias CJ notes that burial disputes will generally have to be resolved quickly, but fails to note that this was not an issue in the present case. ${ }^{112}$ The impact of the requirement for a speedy burial was not considered before the Court handed down a rule which would mostly apply to disputes that needed to be resolved much more quickly. The consequences of this will now be considered.

C The Corollary of a Speedy Burial

\section{Resolving factual controversies}

The corollary of resolving burial disputes quickly is the impact on the nature of the evidence which can be called. Because of the short amount of time to resolve the matter, parties generally give evidence by way of affidavit with no cross-examination of deponents. ${ }^{113}$ Such affidavits usually take the forms of assertions, and counter-assertions

82 (four days), Calma $v$ Sesar, above $\mathrm{n} 10$ (four days), Reece $v$ Little, above n 31 (two days), Mourish $v$ Wynne, above n 90 (3 days), Mankletow v The Public Trustee above n 96 (2 days).

${ }^{107}$ Footnote 102.

${ }^{108}$ Ugle v Bowra, above n 88.

109 Takamore v Clarke (SC), above n 1, at [7]-[12], [75]-[86] per Elias CJ, at [131]-[138], [153]. [156]-[157], [162] per Tipping, McGrath and Blanchard JJ, at [207] per William Young J.

110 At [162].

111 At [138].

112 At [86].

${ }^{113}$ Dodd v Jones, above n 82, at [4], Reece v Little, above n 31, at [8]-[15], Dow v Hoskins [2003] VSC 206 at [5], Jones v Dodd, above n 82, at 330, Mourish $v$ Wynee, above n 90, at [3]-[4], Doherty v Doherty, above n 102, at [12], Mankletow v Public Trustee, above n 96, at [6]-[11] Ugle v Bowra, above n 88, at [1], [3]-[5], Keller $v$ Keller, above n 90, at [1], [4], [15]. 
favourable to the party's case, ${ }^{114}$ and includes evidence such as the deceased's preference as to burial, ${ }^{115}$ evidence of the parties relationship with the deceased, ${ }^{116}$ or the deceased's/party's cultural/spiritual beliefs, and evidence of historical family disputes. ${ }^{117}$ It is inevitable that in such circumstances that factual controversies. These types of evidence are not readily verifiable. ${ }^{118}$ Further there is no incentive for parties to be conservative in their pleaded allegations, as there is no robust approach to scrutinise such evidence except with reference to other pleaded allegations. These of course might also lack veracity. Because such disputes must be resolved quickly without the benefit of time, or hearing from the witness orally or being able to cross-examine them, it is incredibly difficult (if not impossible) to assess the credibility of what the deponents are saying, or otherwise resolve the controversy. ${ }^{119}$

The benefits of "live evidence" ${ }^{120}$ and cross-examination ${ }^{121}$ have been called into serious question by recent studies and judicial decisions. ${ }^{122}$ A number of failings are argued. For example with oral evidence Bond and Depaulo note, "the average person discriminates [through visual demeanour] lies from truths at a level slightly better than he or she could achieve by flipping a coin”. ${ }^{123}$ With regards to cross-examination it is said that, rather than being “...the servant of truth”, ${ }^{124}$ it results in otherwise truthful or reliable witnesses being

\footnotetext{
${ }^{114}$ Keller v Keller, above n 90, at [17], Mankletow v Public Trustee, above n 96, at [2], [12], Dodd v Jones, above n 82, at [25]-[26].

${ }^{115}$ Doherty v Doherty, above n 102, at [4], Dodd v Jones, above n 82, at [28], Reece v Little, above n 31, at [67]-[69], Meier v Bell, above n 82, at 3, Mankletow v Public Trustee, above n 96, at [5], Jones v Dodd, above n 82, at [14]-[15], Ugle v Bowra, above n 88, at [14].

${ }^{116}$ Dodd v Jones, above n 82, at [9]-[11], Reece v Little, above n 31, at [24]-[37], Meier v Bell, above n 82, at 2, Mourish v Wynne, above n 90, at [6]-[10], [45], Mankletow v Public Trustee, above n 96, at [2], [21], Jones v Dodd, above n 82, at [9]-[10], [13], Doherty v Doherty, above n 102, at [2], [6], [9], Burrows v Cramley, above n 102, at [1], [5], Ugle v Bowra, above n 88, at [9].

${ }^{117}$ Dow v Hoskins, above n 113, at [38], Dodd v Jones, above n 82, at [16], Reece v Little, above n 31, at [38], [71]-[74], Meier v Bell, above n 82, at 3, Mankletow v Public Trustee, above n 96, at [12], Jones v Dodd, above n 82, at [14], [16]-[17], [25], Mourish v Wynee, above n 90, at [37], Doherty v Doherty, above n 102, at [3]-[4], [10]-[12], Burrows v Cramley, above n 102, at [30], Keller v Keller, above n 90, at [3], Ugle v Bowra, above n 88, at [10].

118 Takamore $v$ Clarke (SC), above n 1, at [11].

${ }^{119}$ Ugle v Bowra, above n 88, at [1], [4].

${ }^{120}$ Evidence Act 2006, s 83. See Paul Roberts and Adrian Zuckerman Criminal Evidence (2nd ed, Oxford University Press, Oxford, 2010) at 292.

${ }^{121}$ Evidence Act 2006, s 4 definition of "leading question".

${ }^{122}$ Elisabeth McDonald Principles of Evidence in Criminal Cases (Wellington, Thomson Reuters, 2012) at 60-61, 84-85, 130-133.

${ }^{123}$ Charles Bond and Bello DePaulo “Accuracy of Deception Judgments” (2006) 10 Personality and Social Psychology Review 214 at 299. See also Sigfried L Sporer and Barbera Schwandt "Moderators of NonVerbal Indicators of Deception: A Meta-Analytic Synthesis” (2007) 13 Psychology, Public Policy and Law 1.

${ }^{124}$ Paul Roberts and Adrian Zuckerman, above n 120, at 296.
} 
made to look deceitful because they are outmanoeuvred by the artful questioning lawyer. ${ }^{125}$

It might be argued that, even assuming burial disputes had the luxury of time on their side, subjecting them to requirements of orality and cross-examination will not necessarily lead to Court's successfully resolving factual disputes. Independent of these studies, at the "coal-face" of practice of civil litigation there is still a perceived need for crossexamination and orality. ${ }^{126}$ And this is reflected in the law as it currently exists; for example the inability to cross-examine is seen as an important consideration against admissibility of hearsay, ${ }^{127}$ and is encapsulated in the minimum standards of due process for criminal trials. ${ }^{128}$ Such primacy points to the conclusion that our current institutional framework for the resolution of disputes deems cross-examination and orality to be a reliable method of assessing the credibility of witnesses. It should also be conceded that to fully resolve a factual dispute, time is necessary. ${ }^{129}$ For parties to fully prepare their cases all relevant documentary evidence, and witnesses (especially third parties) needs to be gathered, and this allows evidentiary matters and disputes to be fully developed and resolved by the Court. Consequently, even in light of recent studies which call into question the efficacy of orality and cross-examination, time is still the real enemy of the just resolution of factual disputes in burial cases. ${ }^{130}$ This will be illustrated later, with reference to the facts of the present case.

Judges resolving burial disputes are placed in a serious predicament; the contested evidence can be highly relevant or even determinative, but where faced with two disparate views of what happened, how do they determine what the truth is? A judge might choose to make a calculated guess as to what actually happened, and this has happened in a number of Australian decisions. ${ }^{131}$ The risk with this is that the judge gets it wrong; and

\footnotetext{
125 Ibid.

${ }^{126} R$ v L [1994] 2 NZLR 54 (CA) at 61.

${ }^{127}$ Richard Mahoney and others The Evidence Act 2006: Act and Analysis (2nd ed, Brookers, Wellington, 2010) at 74, $R v L$, above n 126, at 63, $R v$ Aekins DC Auckland CRI-2006-004-13245, 16 August 2007 at [50].

${ }^{128}$ New Zealand Bill of Rights Act 1990, s 25(f).

${ }^{129}$ Ugle v Bowra, above n 88, at [1], Dow v Hoskins, above n 113, at [18],

${ }^{130}$ Brian L Josias "Burying the Hatchet in Burial Disputes: Applying Alternative Dispute Resolution to Disputes Concerning the Interment of Bodies” (2003-2004) 79 Notre Dame L Rev 1141 at 1154.

${ }^{131}$ Dow v Hoskins, above n 128, at [34], Mankletow v Public Trustee, above n 96, at [5], [29]-[30], Dodd v Jones, above n 82, at [25], Mourish v Wynee, above n 90, at [34], Leeburn v Derndeorfer, above n 96, at [32], Reece $v$ Little, above n 31, at [45]-[65].
} 
this undermines any claim that the dispute was resolved in accordance with its merits. And such findings of facts do a serious injustice to the party whom they are made against (contrary to the entire purpose of a merits-based test).

Alternatively, a judge might also choose to not determine the controversy and avoid making a dispositive finding of fact, and resolve the dispute considering other factors. This has also occurred in a number of Australian decisions. ${ }^{132}$ But this ultimately undermines the entire purpose of a merits-based test, the just resolution of burial disputes based on the entire circumstances of the case. One cannot resolve a dispute justly by ignoring one of the factual issues that properly bears on the resolution of the matter, as the unresolved fact may have resulted in a different outcome. Either the judge is forced resolve the debate based on contradictory evidence with no means (or time) to adequately do so, or they ignore relevant (but contradictory evidence) and otherwise attempt to resolve the dispute on uncontroverted facts. Equally unpalatable as the above scenario, the outcome is the resolution of the dispute expressly at odds with the underlying policy rationale of the applicable legal test.

In Takamore, the key feature which influenced the move towards a prescriptive test when resolving burial disputes in Australia was absent; the need for a speedy burial. ${ }^{133}$ The consequences of this can be clearly seen where the Supreme Court felt it was in a position to determine that the deceased had not turned his back on his cultural beliefs. ${ }^{134}$ The Supreme Court had the benefit of reviewing the evidence of all relevant witnesses to whom the deceased had expressed his views on his Māori heritage, including the countervailing evidence of his mother, ${ }^{135}$ and expert witnesses on the urbanisation of Māori. ${ }^{136}$ Even more crucial, the Court had a considerable period of time to consider the ramifications of the evidence and take a more robust approach when scrutinising it. ${ }^{137}$ This ultimately led to the Court's concluding that the inference drawn in the High Court (that

\footnotetext{
${ }^{132}$ Dodd v Jones, above n 82, at [28], Jones v Dodd, above n 82, at [18], [25], Mourish v Wynee, above n 90, at [12], [16], [40], Doherty v Doherty, above n 102, at [14], Leeburn v Derndeorfer, above n 96, at [2], [4], [8], Keller $v$ Keller, above n 90, at [18]-[23], [25], Ugle v Bowra, above n 88, at [4], [7], [13]-[14], [16], ${ }^{133}$ Meier v Bell, above n 82, at 3, Calma v Sesar, above n 10, at 452.

${ }^{134}$ At [17], [30], [99] per Elias CJ, at [110] per per Tipping, McGrath and Blanchard JJ, at [175] per William Young J.

${ }^{135}$ Clarke v Takamore (HC), above n 3, at [15], Takamore v Clarke (CA), above n 3, at [160].

${ }^{136}$ Clarke v Takamore (HC), above n 3, at [74]-[75], Takamore v Clarke (CA), above n 3, at [158].

${ }^{137}$ Footnote 102.
} 
the deceased had turned his back on his tribal roots and tikanga), ${ }^{138}$ was unmerited, because the deceased may have said different things to different people about his views on his Māori heritage (to please them). ${ }^{139}$ In this context, it was ironic for the Chief Justice to dismiss the difficulties of resolving factual controversies under a merits-based approach, when she had the luxury of time on her side. The way in which tikanga was dealt with in this case also provides a useful illustration of another issue that arises in the application of a merits-based test, that is arbitrary marginalisation of relevant factors.

\section{Balancing Competing Factors}

The second area of difficulty in applying a merits-based test is weighing competing factors to determine which claimant should be allowed to resolve the issue of burial. This is not so much a corollary of the need to ensure expeditious burial, but the difficulties of balancing competing . Though not necessarily a novel issue faced by the judiciary, ${ }^{140}$ a unique feature in the case of the burial disputes is the absence of a clear legal framework which offers guidance when weighing up the competing factors. The position can be readily contrasted to say, an application for security of costs. ${ }^{141}$ The relevant Court rules and cases prescribes a clear legal framework through which it is possible to cogently balance competing factors when determining whether security should be required. ${ }^{142}$

The position is quite different in case of burial disputes. The issue was expressed concisely by Doyle CJ in the Australian Supreme Court decision in Dodd v Jones: ${ }^{143}$

"Sadly, the problem before me is really insoluble in one sense. It is impossible in any realistic sense to weigh the competing claims and arrive at what one would call a legal judgment."

Three features of burial disputes make it difficult to balance the competing claims of the parties under a merits-based test. Firstly burial disputes involve the consideration of a wide

\footnotetext{
${ }^{138}$ Clarke v Takamore (HC), above n 3, at [71].

${ }^{139}$ Takamore v Clarke (CA), above n 3, at [161].

${ }^{140}$ Peter Spiller Dispute Resolution in New Zealand (2nd ed, Oxford University Press, New York, 2007) at 178. $N \vee N[1980] 2$ NZLR 38 (CA) at 46.

${ }^{141}$ High Court Rules, r 5.45 .

${ }^{142}$ Andrew Beck, above n 48, at 174, A S McLachlan Ltd v MEL Network Ltd (2002) 16 PRNZ 747 (CA) at [15]-[16], Bell-Booth Group Ltd v Attorney-General (1986) 1 PRNZ 457 (HC) at 16, Highgate on Broadway Ltd v Devine [2012] NZHC 2288 at [23].

${ }^{143}$ Jones $v$ Dodd, above n 82, at [36].
} 
variety of disparate factors. ${ }^{144}$ Secondly such factors are not readily comparable in the sense that they will often be equally important. ${ }^{145}$ Thirdly, the win/lose nature of burial disputes requires the judge to make a decision, the inability to compromise meaning one party must undeservingly lose out. ${ }^{146}$ The result is that judges are forced to attempt to unconvincingly resolve burial disputes in accordance with their supposed merits, when in reality both parties have equally meritorious claims. In many cases the underlying assumption of a merits-based approach is incorrect; there is no normatively correct outcome, only the pressing need for a decision to be made. ${ }^{147}$ The judiciary are forced to arbitrarily undermine particular factors so as to give the appearance of a cogent "legal judgment”. However as identified by Doyle CJ in Dodd, aspiring to such a standard of legal reasoning is a fallacy in the context of burial disputes, because there is often no one "right" answer. Examples of these scenarios from Australian cases and Takamore will be discussed below. The ultimate results are ad hoc and unfair, which only goes to further highlight the failings of a merits-based approach.

The spurious attempts of some judges to marginalise particular factors is only natural; the alternative is to admit that burial disputes are often so finely balanced that it is impossible to resolve them fairly. In Takamore, the Chief Justice goes to great lengths to stress the importance of tikanga when resolving burial disputes, so much so, that it was one of the key reasons she rejected a prescriptive approach. ${ }^{148}$ Her ultimate conclusion is then somewhat surprising, that the appellants claim (supported by tikanga) was outweighed by that of the respondents because of the deceased's original decision to follow the respondent when she moved to Christchurch. ${ }^{149}$ In an attempt to provide a more sound explanation (in light of the earlier primacy given to tikanga), the Judge marginalises tikanga (and the support it offered the appellants claim) by stating that “... resolution by the Court of the present dispute does not preclude reconciliation in accordance with tikanga for the future.”150 Her argument appears to be that, though the appellant (and her

\footnotetext{
${ }^{144}$ See cases in Footnotes 114-117.

${ }^{145}$ Dodd v Jones, above n 82, at [29], [36], Burrows v Cramley, above n 102, at [36], Keller v Keller, above n 90, [25], Ugle v Bowra, above n 88, at [23].

${ }^{146}$ Calma v Sesar, above n 10, at 452, Dodd v Jones, above n 82, at [38], Mourish v Wynee, above n 90, at [46], Doherty v Doherty, above n 102, at [34], Leeburn v Derndeorfer, above n 96, at [9]-[10], Burrows v Cramley, above n 102, at [31], [36], Reece v Little, above n 31, at [98].

147 Ibid.

148 At [82].

149 At [102]-[105].

150 At [102].
} 
wider kin group) have lost in the present case, future claims based on tikanga may well succeed. The present result (dismissing those beliefs as being less important than the respondent's relationship with the deceased and his life choices) is then justified.

This argument is unpersuasive for a number of reasons. Firstly it would appear to be inconsistent with precedent; essentially two litigated burial disputes have occurred in New Zealand during the last century, it is highly unlikely any future burial disputes will arise for this to occur. ${ }^{151}$ Secondly this pre-empts the resolution of future claims, the present claimants culture beliefs are abruptly dismissed by the Chief Justice for the promise that they may be recognised in future cases. But under a merits-based test, such an outcome is hardly guaranteed; the infinite factual circumstances present in the lives of New Zealanders would indicate that their will almost always be countervailing factors present to challenge cultural claims. Thirdly, it is difficult to rationalise why the fact future claims supported by tikanga might be upheld (and which would be resolved on their own facts), should be relevant to the dismissal of the present one, as once again, each case will turn on its own facts. To the extent such a line was a throwaway one, the Chief Justice's attempts to salve what appears to be a guilty conscience only goes to demonstrate her apparent difficulty in balancing the present claims.

Neither is this an isolated example. ${ }^{152}$ In Dodd $v$ Jones, Doyle CJ is unable to reconcile the competing cultural claims of the deceased's father, and the contrasting claims of the deceased's close de facto partner. ${ }^{153}$ However, because the dispute has to be resolved, the Judge prefers the claim of the deceased's de facto partner because she would have been entitled to the grant of letters of administration. ${ }^{154}$ Because her claim was supported by the common law (but the father's cultural claim was not) hers was to be preferred. It is difficult to see why the fact the partners claim in this case was supported by the common law (enshrined in the High Court Rules in New Zealand) ${ }^{155}$ justified an outcome in her favour. This is inconsistent with a merits-based approach because the common law appoints an administrator in accordance with a hierarchy of those with a beneficial interest in the deceased's estate, rather than the person who seems to have the strongest

\footnotetext{
${ }^{151}$ Takamore $v$ Clarke (SC), above n 1, at [10]. See Footnote 2.

${ }^{152}$ Reece $v$ Little, above n 31, at [73]-[74].

${ }^{153}$ Dodd $v$ Jones, above n 82, at [36]-[38].

154 Ibid.

155 See Footnote 42.
} 
claim to decide where the deceased should be buried (with reference to the wider circumstances of the dispute). ${ }^{156}$ This demonstrates that such disputes are often so finely balanced that to resolve them solely based on their merits is not possible, and recourse to practical considerations (such a where the body is located or which party has the most advanced funeral preparations) are necessary. ${ }^{157}$ This calls into question the need (or efficacy) of merits-based approach. The poignant question becomes, what is the alternative?

\section{Conclusion and Reform}

A The Injustice of a Merits-Based Approach

Merits-based resolution has been advocated for time and time again in cases because it appears unpalatable to members of the judiciary that disputes are resolved other than in accordance with their merits. ${ }^{158}$ The need to speedily resolve burial disputes and the difficulty of weighing competing factors relevant to such claims, means that a meritsbased test does not result in just decisions. The result is that the overriding policy considerations in favour of such an approach falls away. To the extent this appears to be a generalisation, it is argued that it is illustrative of what would happen in the majority of cases. In decisions of such importance to the parties and society at large, the law should deal in realities rather than create a rule catering to exceptional cases which are relatively clear-cut.

The resolution of disputes of such monument other than in accordance with their merits might seem distasteful. ${ }^{159}$ This is especially so when fundamental values such as spiritual and cultural beliefs are at stake. The relevance of human rights in the context of burial disputes only highlights the inadequacies of judicial involvement, exemplifying their

\footnotetext{
156 At [74].

${ }^{157}$ Takamore v Clarke (SC), above n 1, at [77]. Mankletow v Public Trustee, above n 96, at [29]-[30], Jones $v$ Dodd, above n 82, at [55], [64]-[65], Mourish $v$ Wynee, above n 90, at [42]-[43], Burrows v Cramley, above n 102, at [27], [30], [32]-[35], Ugle v Bowra, above n 88, at [21], Reece v Little, above n 31, at [89]. ${ }^{158}$ Takamore v Clarke (SC), above n 1, at [86], [162]-[163], Jones v Dodd, above n 82, at [40]. Dodd v Jones, above n 82, at [4], Doherty v Doherty, above n 102, at [16], Leeburn v Derndeorfer, above n 96, at [16]. 159 At [88].
} 
inability coherently and correctly balance conflicting rights. ${ }^{160}$ Contrasting judicial opinion about the role of the Courts only goes to further show that Judges themselves are aware that the fair resolution of burial disputes may not be possible. ${ }^{161}$ The role of the Court in burial disputes need not be a negative one; the judiciary are well placed to carry out a supervisory role applying a prescriptive approach, which could act as the necessary backstop where disputes cannot be resolved inter-parties.

\section{B Reform}

The role of the Court as ultimate arbiter can be obviated with every effort being made to resolve the dispute through institutionally-backed ADR. A recurring theme in Takamore (or lack thereof) is the sheer lack of case law in New Zealand in terms of burial disputes. ${ }^{162}$ Happily, those few cases which fall through the cracks of amicable interparties resolution might yet be saved from the battering process of litigation through a mandatory requirement that parties attend mediation before going to Court. ${ }^{163}$ This might be analogous in form to mandatory mediation in the employment law context, ${ }^{164}$ and could be tacked onto to an existing government funded mediation services to save costs (the number of burial disputes in New Zealand would not justify the creation of an additional mediation service).

The advantages of mediation over litigation in this context would include the flexibility offered in process and outcome, empowering the parties to resolve the dispute as they choose, and thereby mitigating the win/lose nature of burial disputes under a Court orientated process. Such a process allows for the parties to have their own beliefs and values heard and recognised, ${ }^{165}$ and mediation is also recognised as being eminently suited to cross-cultural disputes, as well as resonating with cultural dispute resolution processes. ${ }^{166}$ Disadvantages such as loss of precedential value are arguably moot, as the

\footnotetext{
${ }^{160}$ See [91]-[108] for the Chief Justices balancing exercise in resolving the dispute, compare with the majority's approach at [165]-[170], and compare Andrew Butler and Petra Butler The New Zealand Bill of Rights Act: a commentary (LexisNexis, Wellington, 2005) at 124-127.

${ }^{161}$ Heather Conway "Dead, but not Buried: Bodies, Burial and Family Conflicts” (2003) LS 423 at 430.

${ }^{162}$ Takamore v Clarke (SC), above n 1, at [62].

${ }^{163}$ Peter Spiller, above n 140, at 22. Brian L Josias above n 130, at 1116.

${ }^{164}$ Employment Relations Act 2000, ss 159, 188. Peter Spiller, above n 140, at 236.

${ }^{165}$ Lela Porter Love "Mediation of Probate Matters: Leaving a Valuable Legacy" (2000-2001) 1 Pepp Disp Resol LJ 255 at 259.

${ }^{166}$ Yvonne Oldsfield “Disputes Over Internment and Cremation: the Mediation Option” (LLM Research Paper, Laws 536: Negotiation and Mediation, Victoria University of Wellington, 2013) at 15-17, Peter Spiller, above n 140, at 68.
} 
highly personal nature of such disputes means they essentially turn on their own facts. Other practical benefits would include speedier resolution, less expense, and the preservation or transformation of relationships. ${ }^{167}$ The last point is key, many burial disputes will be a manifestation of underlying breakdown in the party's relationships rather than a genuine controversy about where the deceased should be buried. ${ }^{168}$ Courts are illsuited to resolve deep-seated familial feuds. ${ }^{169}$ Justice is arguably best served by the law providing the parties with the tools to resolve the dispute themselves, and perhaps relationship issues as well.

However neither is mediation a perfect fit. A number of issues arise. Firstly mandatory mediation in itself is disempowering to the parties; as it is non-consensual. However as Peter Spiller notes, consent in this context is focused on outcome rather than entry. ${ }^{170}$ The outcome must still voluntarily be agreed to. Evidence from other statutory regimes which impose mandatory mediation demonstrate that their involuntary nature does not undermine effectiveness in terms of resolving disputes. ${ }^{171}$

Another issue is the relationship between mandatory mediation and the Court (as ultimate back-stop) in terms of the way it resolves burial disputes. It might be argued that if a prescriptive approach is applied by the Court, this could incentivise the party who is ultimately entitled under such a regime to refuse to co-operate during the mediation process, because they get to decide where to bury the deceased if the matter goes to Court. A tenable solution could be to impose a positive obligation on the parties to approach mediation in good faith, breach of which would allow the Court to alter the order of priority under the prescriptive regime. This would act as a deterrent to the entitled party seeking to undermine the mediation process merely because they are entitled to decide under the prescriptive regime (which is only in place because of the need to ensure the deceased is buried where the parties cannot agree). Such a solution is not in itself without difficulties, as the nature of such an obligation (and what entailed a breach) would have to

\footnotetext{
${ }^{167}$ Brian L Josias, above n 130, at 1176.

${ }^{168}$ Heather Conway and John Stannard "The Honours of Hades: Death, Emotion and the Law of Burial Disputes” (2011) 343 UNSW LJ 860 at 862, Leeburn v Derndeorfer, above n 96, at [9].

${ }^{169}$ Keller v Keller, above n 90, at [15].

${ }^{170}$ Peter Spiller, above n 140, at 73.

171 Ibid.
} 
be defined. However it is worth considering and draws support from commentators who argue for the imposition of a similar duty in the context of ethics and negotiation. ${ }^{172}$

The final issue is the need for early intervention in burial disputes. ${ }^{173}$ This is demonstrated by the facts of the present case; lack of amicable intervention prior to the uplifting of the deceased's remains resulted in a raw, intractable, and very public burial dispute. ${ }^{174}$ Numerous attempts at mediation or negotiation between the parties failed over the five years of litigation. ${ }^{175}$ The key issue in this context was mediator-led intervention needed to occur prior to the stage where attitudes hardened and bitterness became entrenched between the parties, especially before the Kutarere family uplifted the deceased's body. Any reform would therefore need to be coupled with a public awareness campaign to ensure New Zealanders were aware of mediation services.

In terms of litigation as the "default option” 176 there are multiple ways in which Court review might be carried out, depending on whether this is done with reference to a first decider or unilateral arrangements made by one the parties. ${ }^{177}$ Insofar as out of Court resolution is not possible, a tentative alternative to a merits-based approach could be a prescriptive approach, via the hard form of a decider rule, ${ }^{178}$ perhaps reflected in a statutory regime which outlines a priority of decision-makers (as has been done in British Columbia). ${ }^{179}$ Legislative reform would additionally allow a full consideration of all the policy issues at play, something not possible if burial disputes were to be resolved solely via judge-made law. ${ }^{180}$ Reform would focus on establishing a regime which resolves the dispute outside of Court, providing a cheap, speedy, and practical solution to a dispute that must be resolved. ${ }^{181}$ This is positively desirable, the alternative default option is litigation under a merits-based approach, with the associated costs, damage to relationships, time-

\footnotetext{
${ }^{172}$ D W McLauchlan “The Agreement to Negotiate in Good Faith: A Non-Justiciable Contract?” (2005) 11 NZBLQ 454 at 472. Peter Spiller, above n 140, at 57.

${ }^{173}$ Yvonne Oldsfield, above n 165, at 19.

174 Shane Cowlishaw and Olivia Wannan "Takamore body-snatching case could lead to standoff” (19 December 2012) Stuff <www.stuff.co.nz>, Mike Watson "Five year tug of love over body nears end” (10 March 2013) <www.stuff.co.nz>.

${ }_{175}$ Clarke v Takamore (HC), above n 3, at [104], Takamore v Clarke (CA), above n 3, at [6]. Footnote 214.

${ }^{176}$ Brian L Josias, above n 130, at 1154.

${ }^{177}$ Footnote 93, Takamore v Clarke, above n 1, at [68].

${ }^{178}$ At [171]-[172].

${ }^{179}$ Cremation, Interment and Funeral Services Act BC 2004 c 35, s 5.

${ }^{180}$ At [80]. Peter Spiller, above 140, at 178-179.

${ }^{181}$ At [153]. Metropolitan v Essere [1991] 3 NZLR 170 (CA) at 173. Footnotes 164-165.
} 
delays, disempowerment, and limits as to remedies making it as less than attractive option for parties and society generally. ${ }^{182}$

In this context the words of Martin J that "A legal solution [to burial disputes] must be found...” should be borne in mind. Not all disputes can be resolved through agreement; therefore the law must have a solution, and this where the Court comes in. Australia's lesson has been that the judicial application of a merits-based test does not produce the kinds of outcomes it seeks provide. The real injustice in the entire Takamore saga would be to not learn from this.

${ }^{182}$ Peter Spiller, above 140, at 22, Brian L Josias, above n 130, at 1166. 


\section{Bibliography}

\section{A Cases}

$1 \quad$ New Zealand

A S McLachlan Ltd v MEL Network Ltd (2002) 16 PRNZ 747 (CA).

Bell-Booth Group Ltd v Attorney-General (1986) 1 PRNZ 457 (HC).

Clarke v Takamore [2010] 2 NZLR 525 (HC).

Craddock v Crowhen (1995) 1 NZSC 40,331 at 12.

Gailey v Gordon [2003] 2 NZLR 192 (HC).

Highgate on Broadway Ltd v Devine [2012] NZHC 2288.

Metropolitan v Essere [1991] 3 NZLR 170 (CA).

Murdoch $v$ Rhind [1945] NZLR 425 (SC).

$N \vee N[1980] 2$ NZLR 38 (CA).

$R v$ Aekins DC Auckland CRI-2006-004-13245, 16 August 2007.

$R v L[1994] 2$ NZLR 54 (CA).

Re The Motorola Superannuation Fund [2001] 3 NZLR 50 (HC.

Siemer v Solicitor-General [2013] NZSC 68.

Soljan v Spencer [1984] 1 NLZR 618 (CA). 
Takamore v Clarke [2011] NZCA 587.

Takamore v Clarke [2012] NZSC 116.

Tapora v Tapora CA206/96, 28 August 1996.

Wrightson Ltd v Fletcher Challenge Nominees Ltd (1998) 1 NZSC 40,388.

$2 \quad$ Australia

$A B \vee C D$ [2007] NSWSC 1474.

Burrows v Cramley [2002] WASC 47.

Calma v Sesar (1992) 106 FLR 446 (NTSC).

Doherty v Doherty [2006] QSC 257.

Dodd v Jones [1999] SASC 458.

Dow v Hoskins [2003] VSC 206.

Jones v Dodd [1999] SASC 125.

Keller v Keller [2007] VSC 118.

Leeburn v Derndorfer [2004] VSC 172.

Mankletow v Public Trustee [2001] WASC 290.

Meier v Bell SC Victoria BC9700457, 3 March 1997.

Mourish v Wynee [2009] WASC 85. 
Reece v Little [2009] WASC 30.

Smith v Tamworh City Council (1997) 41 NSWLR 680 (SC).

Ugle v Bowra [2007] WASC 82.

$3 \quad$ England

Associated Provincial Picture Houses Ltd v Wednesbury Corporation [1947] EWCA Civ 1.

Burrows v HM Coroner for Preston [2008] 2 FLR 1225 (QB).

Futter v Futter [2011] EWCA Civ 197.

Re Hasting-Bass [1974] 2 All ER 193.

Re Supply of Ready Mixed Concrete (No.2) [1992] 2 QB 213.

Williams v Williams (1882) 20 ChD 659.

\section{B Legislation}

$1 \quad$ New Zealand

i $\quad$ Statutes

Administration Act 1968.

Evidence Act 2006.

Employment Relations Act 2000.

New Zealand Bill of Rights Act 1990. 
ii Subordinate Legislation

High Court Rules.

$2 \quad$ Canada

i $\quad$ Statutes

Cremation, Interment and Funeral Services Act BC 2004 с 35.

C Books

Andrew Beck Principles of Civil Procedure (3rd ed, Brookers, Wellington, 2012).

Andrew Butler and Petra Butler The New Zealand Bill of Rights Act: a commentary (LexisNexis, Wellington, 2005).

Noel C Kelly and others Garrow and Kelly Law of Trusts and Trustees (6th ed, LexisNexis, Wellington, 2005).

Richard Mahoney and others The Evidence Act 2006: Act and Analysis (2nd ed, Brookers, Wellington, 2010).

Elisabeth McDonald Principles of Evidence in Criminal Cases (Wellington, Thomson Reuters, 2012).

N Richardson Nevill's Law of Trusts, Wills and Administration (10th ed, LexisNexis, Wellington, 2010).

Paul Roberts and Adrian Zuckerman Criminal Evidence (2nd ed, Oxford University Press, Oxford, 2010). 
Peter Spiller Dispute Resolution in New Zealand (2nd ed, Oxford University Press, New York, 2007).

\section{Journal Articles}

Roaslind Atherton “Who owns your body?” (2003) 77 ALJ 178.

Charles Bond and Bello DePaulo “Accuracy of Deception Judgments” (2006) 10

Personality and Social Psychology Review 214.

Heather Conway “Dead, but not Buried: Bodies, Burial and Family Conflicts” (2003) LS 423.

Heather Conway and John Stannard "The Honours of Hades: Death, Emotion and the Law of Burial Disputes” (2011) 343 UNSW LJ 860 at 862.

Brian L Josias "Burying the Hatchet in Burial Disputes: Applying Alternative Dispute Resolution to Disputes Concerning the Interment of Bodies” (2003-2004) 79 Notre Dame L Rev 1141.

Lela Porter Love "Mediation of Probate Matters: Leaving a Valuable Legacy” (2000-2001) 1 Pepp Disp Resol LJ 255.

D W McLauchlan "The Agreement to Negotiate in Good Faith: A Non-Justiciable Contract?” (2005) 11 NZBLQ 454.

Sigfried L Sporer and Barbera Schwandt "Moderators of Non-Verbal Indicators of Deception: A Meta-Analytic Synthesis” (2007) 13 Psychology, Public Policy and Law 1.

\section{E Parliamentary and Government Materials}

Law Commission Court Jurisdiction, Trading Trusts and Other Issues: Review of the Law of Trusts (NZLC IP5, 2011).

Law Commission Māori Custom and Values in New Zealand Law (NZLC SP9, 2001).

\section{F Dissertations and Research Papers}


Fiona Wright ““'Tikanga Māori” What is it doing in New Zealand law?” (LLM Research

Paper, Law, Religion and Values (Laws 527), Victoria University of Wellington, 2006).

Yvonne Oldsfield "Disputes Over Internment and Cremation: the Mediation Option" (LLM Research Paper, Laws 536: Negotiation and Mediation, Victoria University of Wellington, 2013) at 15-17.

\section{H Internet Sources}

Shane Cowlishaw and Olivia Wannan "Takamore body-snatching case could lead to standoff” (19 December 2012) Stuff <www.stuff.co.nz>,

Mike Watson "Five year tug of love over body nears end” (10 March 2013)

$<$ www.stuff.co.nz $>$. 


\section{Word Count}

The text of this paper (excluding abstract, table of contents, footnotes, and bibliography) comprises 7959 words. 